\title{
The Incidence of Epstein-Barr Virus Primary Infection Among Suspected Patients Referred to Namazi Hospital of Shiraz, Iran
}

\author{
Mahsa Moeini ${ }^{1}$; Mazyar Ziyaeyan ${ }^{1,{ }^{*}}$; Sadaf Asaei ${ }^{1}$; Mohammad Amin Behzadi ${ }^{1,2}$ \\ ${ }^{1}$ Microbiology Research Center, Shiraz University of Medical Sciences, Shiraz, IR Iran \\ ${ }^{2}$ Student Research Committee, Shiraz University of Medical Sciences, Shiraz, IR Iran \\ ${ }^{*}$ Corresponding author: Mazyar Ziyaeyan, Microbiology Research Center, Shiraz University of Medical Sciences, Shiraz, IR Iran. Tel: +98-7116474304, Fax: +98-7116474303, \\ E-mail: ziyaeyanm@sums.ac.ir
}

Received: November 10, 2013; Revised: June 14, 2014; Accepted: June 24, 2014

\begin{abstract}
Background: Many children become infected with Epstein-Barr virus (EBV) during their childhood. Since the clinical profile of EBV primary infection is challenging, it is important to use the best diagnostic clinical means. Detection of IgM against viral capsid antigen (VCA) by ELISA has been shown to be a reliable method.

Objectives: This study was conducted to demonstrate the incidence of EBV primary infection, among suspected patients referred to Namazi hospital, Shiraz, Iran.

Patients and Methods: The sample included 346 patients with an age range of 0 to 20 years (6.31 $\pm 4.66: 10.97$ years). A volume of $5 \mathrm{~mL}$ of blood was collected from each case. The patients were divided to four age groups. The sera were tested for the presence of VCA-IgM by commercially available Anti-EBV-VCA ELISA kit.

Results: The results indicated that 104 (30.0\%) of the patients were EBVVCA IgM positive, with no significant difference in the incidence of EBV primary infection between males and females. However, the incidence of infection was significantly different between age group I ( 0 - 5 years) and III ( 11 - 15 years), and also between age group I $(0-5$ years $)$ and IV $(16-20$ years $)(P<0.05)$.

Conclusions: Considering the results, accurate and on time diagnosis of EBV primary infection in both children and adolescents will help prevent unnecessary hospitalization, medication and incorrect medical decisions. In addition, this will decrease further treatment costs and related medical procedures.
\end{abstract}

Keywords: Epstein-Barr virus; Incidence; IgM; Epidemiology

\section{Background}

Human Herpes Virus 4 (HHV-4), also called EpsteinBarr virus (EBV), as a member of Herpesviridae, is one of the most common viruses in humans. Epstein-Barr virus infection frequently causes mononucleosis or glandular fever in teenagers. The infection in infants and children is usually less severe than that of adults. It is commonly associated with non-specific clinical signs and is usually presented by painful sore throat, swollen glands, chills, fever and chronic fatigue syndrome. These symptoms could last for one to six weeks $(1,2)$.

The primary EBV infection in Africa, Southeast Asia and Latin America occurs in early childhood, while in developed countries the first peak of infection seems to be before the first five years of life while the second peak is during adolescence (3). According to epidemiological studies the average age of EBV primary infection is increasing (4), e.g. in US, it ranges from $50 \%$ for 5 year olds to $90 \%$ for 25 years old (5). In Brazil the pattern of positive EBV IgG Ab showed a higher prevalence with increasing age, reaching a peak in the second decade of life (3). In Spain, the distribution of primary infection has shown two peaks, one at the age of two to four years and another at the age of 14 - 18 years (6). A recent study of 94 children in the Republic of China demonstrated that $78.6 \%$ had EBV-VCA IgG by the end of the first year of life and $80.7 \%$ were seropositive by the age of three $(7,8)$. A similar study in Chile revealed that $50 \%$ of children from low and medium socioeconomic level had been primarily infected by the age of two in comparison with $5.9 \%$ of high socioeconomic children of the same age (9). In Malaysian children the presence of EBV-IgM antibody, occurred at four to six months and by eight years many children became infected with EBV (10).

Since the clinical picture of EBV primary infection could be challenging, and because this infection usually causes no symptoms and can be indistinguishable from other mild, brief infections of children such as streptococcal throat infection, it is important to use the best clinical means for diagnosis $(6,10)$. The routine diagnosis of EBV primary infection is based on several serological tests such as indirect fluorescent antibody (IFA), rapid monospot tests (for heterophile antibodies) and enzyme im-

Copyright (C) 2015, Ahvaz Jundishapur University of Medical Sciences. This is an open-access article distributed under the terms of the Creative Commons Attribution-NonCommercial 4.0 International License (http://creativecommons.org/licenses/by-nc/4.0/) which permits copy and redistribute the material just in noncommercial usages, provided the original work is properly cited. 
mune assay (EIA) for detection of early antigens (EA), the viral capsid antigens (VCA) or the EBV nuclear antigen (EBNA) (11-13).

\section{Objectives}

To the best of our knowledge, there is no study on the incidence of EBV primary infection in Iran. The aim of this study was to determine the incidence of EBV primary infection, among Iranian suspected patients who had referred to Namazi Hospital of Fars province (south of Iran) by the ELISA method.

\section{Patients and Methods}

\subsection{Patients}

The studied population consisted of 346 suspected patients who had referred to the Professor Alborzi Clinical Microbiology Research center, Namazi Hospital, Shiraz, southern Iran, during March 2007 to March 2011. The major clinical manifestations of these patients included painful sore throat, swollen glands, chills, fever and tiredness. There were 211 males (61\%) and 135 females (39\%) with an age range of 0 to 20 years (6.31 $\pm 4.66: 10.97$ years). The study population was distributed to four age groups, as follow: group I ( 0 - 5 years, $n=192$ ), group II ( 6 - 10 years, $\mathrm{n}=96)$, group III ( $11-15$ years, $\mathrm{n}=38)$, and group IV ( $16-20$ years, $\mathrm{n}=20$ )

\subsection{Sample Collection and Antibody Detection}

A $5 \mathrm{~mL}$ blood sample was collected from each individual; sera was separated and stored at $-20^{\circ} \mathrm{C}$ for further examination. The IgM antibodies against EBV VCA were evaluated by a standard commercially available ELISA kit (Euroimmun, Lubeck, Germany). The assay was performed according to the manufacturer's instructions.

\subsection{Statistical Analysis}

Descriptive analysis and Chi-square tests were used to explain the results and compare between the incidence of EBV infection in different age and sex groups. The data were analyzed by the SPSS software (SPSS for Windows, version 16, SPSS Inc., Chicago, IL, USA). P values of $<0.05$ were considered statistically significant.

\section{Results}

Out of 346 patients, 104 (30.00\%) were positive for EBV VCA-IgM, from whom $62.5 \%$ and $37.5 \%$ were males and females, respectively. There was no significance difference in the incidence of EBV primary infection between males and females $(P>0.05)$ (Figure 1). Our results showed that $61.5 \%$ of EBV VCA-IgM positive patients belonged to age group I, 30\% to age group II, 5.8\% to age group III and finally $1.9 \%$ to age group IV. Statistical analysis revealed that there were no significant differences between age group
I (64/192) and II (32/96), II (32/96) and III (6/38), III (6/38) and $\operatorname{IV}(2 / 20)(P>0.05)$. However, the incidence of EBV primary infection was significantly different between age groups I and III $(\mathrm{P}<0.05)$ and also between age groups I and IV $(\mathrm{P}<0.05)$ (Figure 2).

\section{Discussion}

Symptomatic acute EBV primary infection is clinically associated with infectious mononucleosis (IM) accompanied by fever, tonsillopharyngitis, hepatosplenomegaly, lymphadenopathy, and the increase of mononuclear blood cell number $(1,14,15)$. Fever, pharyngitis and lymphadenopathy are the classic triad of $\operatorname{IM}(2,14)$. In the present study, the most common symptoms of our cases included fever, temperature reaching $40^{\circ} \mathrm{C}$,

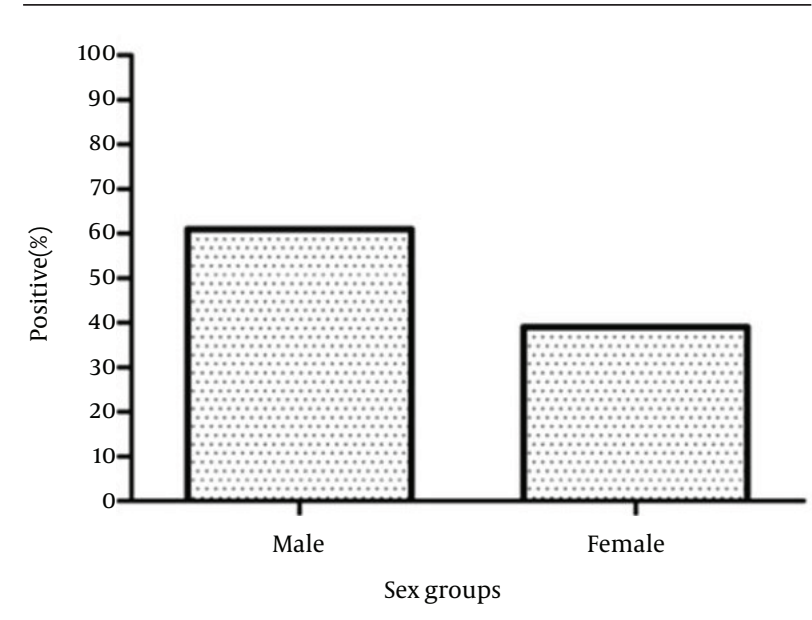

Figure 1. The Incidence of Epstein-Barr Virus Primary Infection in Both Sexes

Figure 2. The Incidence of Epstein-Barr Virus Primary Infection in Different Age Groups

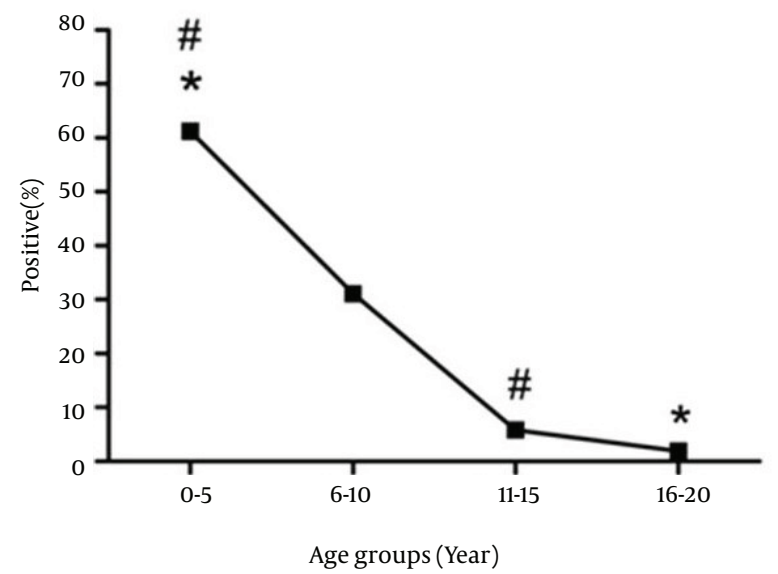

The same symbols indicate significant statistical differences between groups $(\mathrm{P}<0.05)$. 
sore throat with and without exudates and painful cervical lymphadenopathy. However these symptoms were more or less significant between different age groups.

Since the monospot test has an approximate sensitivity and specificity of $85 \%$ and $94 \%$ for diagnosis of EBV infection, and it may be negative in about $50 \%$ of cases under age of $12(1,3)$, definitive diagnosis for EBV infection is based on VCA-IgM and VCA-IgG antibodies detection (8, $14,16,17)$. The presence of VCA-IgM in more than $80 \%$ of acute sera is the best indication for confirming EBV primary infection within four to eight weeks since infection, while after this period such indication disappears. Its shortened presence in very young children is related to the lower titer achieved (14, 17-19). In an earlier study in the United Kingdom, 92\% of EBV infected patients were anti VCA-IgM positive $(14,16)$. Our study showed that $30 \%$ of 346 cases with typical symptomatic EBV infection were VCA-IgM positive.

Different population-based studies have reported various prevalence rates of EBV infection in children, from $20 \%$ to $80 \%$ at age two to three years in different regions. In industrialized and developed countries with high standards of living, EBV primary infection occurs mostly in adolescence (20-22). It was shown that in Malaysian children, primary infection indicated by emergence of EBV IgM antibody, occurred at four to six months of age, while all children were seropositive by age of eight (10). In another study in Japan, anti VCA-IgM positive rate in infants with acute primary infection was $25 \%$ yet $80 \%$ in those four years of age and over (23). In this study, the highest incidence of EBV primary infection belonged to the age group I ( 0 - 5 years ) with a rate of $61.5 \%$. This percentage decreased with age and reached $1.9 \%$ by the age 16 - 20 years.

Previous studies declared that there is no difference in EBV seroprevalence between different genders in children (24-26). In the present study, there was also no significance difference in EBV primary infection incidence between males and females. To sum up, we can conclude that accurate and on time diagnosis of EBV primary infection in both children and adolescents will help prevent unnecessary hospitalization, medication, and incorrect medical decisions. In addition, it will decrease further treatment costs and related medical procedures. Moreover, in most cases, the best means to differentiate EBV primary infection from other infections and malignancies is by detection of IgM specific antibodies against viral capsid antigen (VCA-IgM) in the sera. Among different serological assays, the ELISA test is generally more sensitive and allows rapid diagnosis.

\section{Authors' Contributions}

Mazyar Ziyaeyan developed the original idea and the protocol. Mahsa Moeini wrote the manuscript, and was the guarantor. Sadaf Asaei contributed to the development of the protocol, abstracted data, and prepared the manuscript. Mohammad Amin Behzadi analyzed the data and prepared the manuscript.

\section{Funding/Support}

This study was financially supported by Grant No. 91-16 awarded by the Clinical Microbiology Research Center, Shiraz University of Medical Sciences, Shiraz, Fars, IR Iran.

\section{References}

1. Luzuriaga K, Sullivan JL. Infectious mononucleosis. N Engl J Med. 2010;362(21):1993-2000.

2. Hurt C, Tammaro D. Diagnostic evaluation of mononucleosislike illnesses. Am J Med. 2007;120(10):911 e1-8.

3. Figueira-Silva CM, Pereira FE. Prevalence of Epstein-Barr virus antibodies in healthy children and adolescents in Vitoria, State of Espirito Santo, Brazil. Rev Soc Bras Med Trop. 2004;37(5):409-12.

4. Nishikawa J, Funada H, Miyazaki T, Fujinami H, Miyazono T, Murakami J, et al. Infectious mononucleosis with atypical manifestations accompanied by transient IgM antibody response for cytomegalovirus. J Infect Chemother. 2011;17(5):686-8.

5. Dowd JB, Palermo T, Brite J, McDade TW, Aiello A. Seroprevalence of Epstein-Barr virus infection in U.S. children ages 6-19, 20032010. PLoS One. 2013;8(5).

6. Pariente M, Bartolome J, Lorente S, Crespo MD. [Age distribution of serological profiles of Epstein-Barr virus infection: review of results from a diagnostic laboratory]. Enferm Infecc Microbiol Clin. 2007;25(2):108-10.

7. Niederman JC, Evans AS, Subrahmanyan L, McCollum RW. Prevalence, incidence and persistence of EB virus antibody in young adults. N Engl J Med.1970;282(7):361-5.

8. Du HJ, Zhou L, Liu HT, Wang Q, Zhan SB, Jia ZY, et al. [A serological survey of Epstein-Barr virus infection in children in Beijing]. Zhonghua Shi Yan He Lin Chuang Bing Du Xue Za Zhi. 2008;22(1):30-2.

9. Ferres M, Prado P, Ovalle J, Fuentes R, Villarroel L, Ferreccio C, et al. [Seroprevalence of Epstein Barr virus infection in a healthy population of Santiago de Chile]. Rev Med Chil. 1995;123(12):1447-52.

10. Yadav MS, Malliga N, Ablashi DV. Development of immunity to Epstein-Barr virus in Malaysian children. Microbiologica. 1987;10(1):29-35.

11. Luderer R, Kok M, Niesters HG, Schuurman R, de Weerdt O, Thijsen SF. Real-time Epstein-Barr virus PCR for the diagnosis of primary EBV infections and EBV reactivation. Mol Diagn. 2005;9(4):195-200.

12. Bocian J, Januszkiewicz-Lewandowska D. [Epstein-Barr virus infection - life cycle, methods of diagnosis, associated diseases]. Postepy Hig Med Dosw (Online). 2011;65:286-98.

13. Koidl C, Riedl R, Schweighofer B, Fett S, Bozic M, Marth E. Performance of new enzyme-linked fluorescent assays for detection of Epstein-Barr virus specific antibodies in routine diagnostics. Wien Klin Wochenschr. 2011;123(7-8):230-4.

14. Abdel-Aziz M, El-Hoshy H, Rashed M, Qotb M, Awad S, Naguib N. Epstein-Barr virus infection as a cause of cervical lymphadenopathy in children. Int J Pediatr Otorhinolaryngol. 2011;75(4):564-7.

15. Grose C. The many faces of infectious mononucleosis: the spectrum of Epstein-Barr virus infection in children. Pediatr Rev. 1985;7(2):35-44.

16. Macsween KF, Higgins CD, McAulay KA, Williams H, Harrison $\mathrm{N}$, Swerdlow AJ, et al. Infectious mononucleosis in university students in the United kingdom: evaluation of the clinical features and consequences of the disease. Clin Infect Dis. 2010;50(5):699-706

17. Calderon-Margalit R, Sheffer R, Halperin T, Orr N, Cohen D, Shohat T. A large-scale gastroenteritis outbreak associated with Norovirus in nursing homes. Epidemiol Infect. 2005;133(1):35-40.

18. Shirley WP, Woolley AL, Wiatrak BJ. Pharyngitis and adenotonsillar disease.USA: Elsevier; 2010.

19. Krabbe S, Hesse J, Uldall P. Primary Epstein-Barr virus infection in early childhood. Arch Dis Child.1981;56(1):49-52.

20. Candy B, Chalder T, Cleare AJ, Wessely S, White PD, Hotopf M. 
Recovery from infectious mononucleosis: a case for more than symptomatic therapy? A systematic review. Br J Gen Pract. 2002;52(483):844-51.

21. Okano M. Overview and problematic standpoints of severe chronic active Epstein-Barr virus infection syndrome. Crit Rev Oncol Hematol. 2002;44(3):273-82.

22. Sumaya CV, Ench Y. Epstein-Barr virus infectious mononucleosis in children. II. Heterophil antibody and viral-specific responses. Pediatrics. 1985;75(6):1011-9.

23. Dohno S, Maeda A, Ishiura Y, Sato T, Fujieda M, Wakiguchi H. Diag nosis of infectious mononucleosis caused by Epstein-Barr virus in infants. Pediatr Int. 2010;52(4):536-40.

24. Golubjatnikov R, Allen VD, Steadman M, Del Pilar Olmos B, In horn SL. Prevalence of antibodies to Epstein-Barr virus, cytomegalovirus and Toxoplasma in a Mexican highland community. Am JEpidemiol.1973;97(2):116-24.

25. Lang DJ, Garruto RM, Gajdusek DC. Early acquisition of cytomegalovirus and Epstein-Barr virus antibody in several isolated Melanesian populations. Am J Epidemiol.1977;105(5):480-7.

26. Sumaya CV, Henle W, Henle G, Smith MH, LeBlanc D. Seroepidemiologic study of Epstein-Barr virus infections in a rural community. J Infect Dis. 1975;131(4):403-8. 